\title{
Confronting the Stigma of NAming Jesus as a Victim of SeXual Violence
}

\section{David Tombs ${ }^{1}$}

Pastor Skosana's sermon in 2010 in the township of Khayelitsha outside Stellenbosch on the theme that "Jesus was HIV-positive" attracted worldwide attention. This chapter discusses the controversy around the sermon and Skosana's reason for making this metaphorical identification of Jesus with HIV/AIDS. Although he never meant his sermon to be taken literally, the pastor did expect it to be taken seriously. His serious intention was to break a silence within the church and to express solidarity with people with HIV/AIDS. This chapter is especially interested in Skosana's response to critics who claimed the sermon was insulting and offensive. These criticisms revealed a powerful sense of AIDS stigma within the churches. Skosana's recognition of this problem and his readiness to criticise it for what it really was, offers lessons for other areas of work which are commonly associated with stigma, such as sexual violence.

Recent work has highlighted the role that religious organisations can play in addressing sexual and gender-based violence as a global issue. ${ }^{2}$ This is especially true in South Africa, where churches are central to community life and have a strong influence on social attitudes and values. In the South African census 2001 approximately $80 \%$ of South Africa's population professed to be Christian, and 35 million South Africans belong to a church. As respected institutions with considerable moral authority, they are well placed to offer leadership on responses to the pandemic of gender-based violence attested in research reports and regular news stories. Figures released in June 2018 by the national statistical service of South Africa suggest an estimate of 138 out of every 100,000 women in the country were raped in 2016 and 2017. However, Tearfund's report Breaking the Silence: The Role of the Church in Addressing Sexual Violence in South Africa (2013) shows that a major shift is required for this reporting to occur reliably. In practice, survivors often

This chapter is a revised and expanded version of the conference paper "Naming Jesus as a victim of sexual violence: The role of the churches in confronting the stigma of sexual abuse" at the Global Network in Public Theology Triennial Conference, on Democracy and Social Justice in Glocal Contexts, at University of Stellenbosch (24-26 October 2016). I am grateful to Professor Beverley Haddad, University of KwaZulu-Natal, for insights and comments on an earlier draft of the paper, but all errors and limitations are of course entirely my own.

2 Elisabet Le Roux, Neil Kramm, Nigel Scott, Maggie Sandilands, Lizle Loots, Jill Olivier, Diana Arango \& Veena O'Sullivan, "Getting Dirty: Working with Faith Leaders to Prevent and Respond to Gender-Based Violence", The Review of Faith \& International Affairs, 14:3 (2016):22-35 [https://doi.org/10.1080/15570274.2016.1215837].

3 Statistics South Africa, Crime against Women in South Africa: An In-depth Analysis of the Victims of Crime Survey data 2018, Crime Statistics Series Volume V 2018. Online at: http://bit.ly/322rz0C8 [Accessed 15 July 2018]. 
remain silent because of fears and stigma. The churches can, in turn, deepen this silence and reinforce the stigma associated with sexual violence.

The silence of survivors and the churches provides an important context in which to discuss the significant biblical and historical evidence that Jesus was a victim of sexual violence. Breaking the silence on this claim is long overdue. It is not just a matter of setting the historical record straight. As Skosana's sermon suggests, naming Jesus as a victim of sexual violence can expose stigmatised attitudes within the churches towards survivors of sexual violence. Skosana's sermon shows how naming Jesus as a victim of sexual violence might, nevertheless, help the churches to confront stigmatising attitudes within their own cultures.

In making this connection between Skosana's sermon that "Jesus was HIV-positive" and recent research on Jesus as victim of sexual violence, it must be remembered that Skosana's sermon was metaphorical and not intended as putting forward serious historical or biblical claims. By way of contrast, there is good historical and biblical evidence for recognising Jesus as a victim of sexual violence. This historical and biblical evidence provides all the more reason for biblical scholars, theologians and churches to break the silence, to name Jesus as a victim of sexual violence, and to address the negative reactions and stigmas that this might initially prompt.

\section{Pastor Skosana's Sermons on Jesus as HIV-positive}

Khayelitsha, which means "Our New Home" in Xhosa, is a large township on the Cape Flats alongside the road between Cape Town and Stellenbosch. Pastor Xola Skosana founded the Way of Life Khayelitsha congregation in 1996 with support from the Way of Life congregation in Port Elizabeth, where he had previously been involved as a song writer, psalmist and preacher. His ministry draws on black theology and his Pentecostal Church tradition for his preaching of the gospel. He is ready to be outspoken when he wants to get a message across. For example, in his book Disband the White Church, he discusses the public call he made in 2002 that "[t] he honorable thing to do for the white church in South Africa, is to disband, dissolve, and re-emerge within the black church in poor communities of South Africa". ${ }^{4}$

For Skosana, HIV/AIDS is an unavoidable and immediate concern in Khayelitsha and other poor communities. HIV/AIDS is not a distant problem which the church can pretend not to see or safely confine to a detached discussion. Two of Skosana's sisters died of AIDS, one in 2003 and another in 2010. In August 2010 Skosana preached his dramatic three-part sermon series that "Jesus was HIV-positive". The sermon launched a campaign to encourage people to know their HIV status. At the time the congregation was meeting at Luhlaza High School hall and during the third of the three services Skosana took an HIV test in front of the congregation, along with a hundred members of the church. ${ }^{5}$

$4 \quad$ Xola Skosana, Disband the White Church (Cape Town: Lesedi House Publishers), First published as The Things We Feel, Things We Dare Not Say, Disband the White Church, 2006.

$5 \quad$ Mohammed Allie, "'Jesus had HIV' Sermon Sparks South African Fury", BBC News, Cape Town (1 November 2010), online at: [https://bbc.in/320EHDk]. Udani Samaraseker, "'Jesus had HIV' draws backlash, world hype", Pretoria News (6 September 2010), 3. David Smith, "Pastor's 'Jesus had HIV' Sermon Angers South African Christians", The Guardian (25 August 2010) http://bit.ly/33cY8sP [Accessed 5 March 2016] 
In the sermon Skosana drew on the parable of judgement in Matthew 25 to show that Christ is to be found in the sick. "In many parts of the Bible, God put himself in the position of the destitute, the sick, the marginalised," he said. "When we attend to those who are sick, we are attending to him. When we ignore people who are sick, we are ignoring him."'6

The theological connection between Christ and AIDS was not completely new. African theologians had taken the lead in pioneering this area of theology in the previous decade. Adriaan van Klinken provides a valuable overview of African theologians who, before Skosana's sermon, had already drawn on verses in Paul to write and speak on the church, the Body of Christ and AIDS. ${ }^{7}$ This overview includes work by Fulata Moyo (Malawi), Musa Dube (Botswana), Agbonkhianmeghe Orobator (Nigeria), Isabel Phiri (Malawi), Denise Ackermann, Beverley Haddad and Sarojini Nadar (South Africa), and others involved in the Circle of Concerned African Theologians. The painting "Man of Sorrows: Christ With AIDS" (1993) by AIDS activist and artist Maxwell Lawton had also made a connection along similar lines, and another version had been painted for St George's Cathedral, Cape Town. However, Skosana's sermon was a particularly dramatic and forceful expression of this idea, not least because he spoke more directly of Jesus rather than using the more theological language of "the body of Christ".

In terms of a straightforward historical claim the idea that Jesus was HIV-positive is self-evidently anachronistic. Skosana made clear "Of course, there's no scientific evidence that Jesus had the HIV virus in his bloodstream". ${ }^{8}$ The identification of Jesus as HIV-positive that he makes through Isaiah 53 and Matthew 25 is theological and metaphorical. It allows Skosana to connect the lived historical experience of HIV/AIDS in the township directly with Christ's own experience of suffering. ${ }^{9}$

The sermon prompted sharply divided reactions. A supporter of Skosana wrote to the Cape Times to say: "One of the most powerful things we can do as a church right now is to say Jesus was and is HIV-positive". ${ }^{10}$ Mark Heywood, the deputy chairperson of South Africa's National Aids Council, was reported as saying: "I applaud his actions. It's very important that church leaders set an example, destigmatising HIV and encouraging testing so people know their status" (Smith 2010). However, others questioned whether the sermon would have the positive consequence he intended.

Some people living with HIV had already expressed reservations about speaking of Christ as HIV-positive, and spoken of the importance of finding hope in the

6 Smith, "Pastor's 'Jesus had HIV' Sermon".

7 Adriaan van Klinken, "When the Body of Christ Has AIDS: A Theological Metaphor for Global Solidarity in Light of HIV and AIDS", in International Journal of Public Theology 4:4, (2010):446-465 [https://doi.org/10.1163/156973210X526418].

$8 \quad$ Allie, "'Jesus had HIV' Sermon".

9 For wider theological and church perspectives on HIV/AIDS, see especially Beverley Haddad, Religion and HIV: Charting the Terrain (Pietermaritzburg: UKZN Press, 2011). Gideon B. Byamugisha, John Joshva Raj \& Ezra Chitando (eds.), Is the Body of Christ HIV Positive? New Ecclesiological Christologies in the Context of HIV Positive Communities (New Delhi: ISPCK, 2012).

10 Allie, "'Jesus had HIV' Sermon". 
HIV-negative blood of Jesus. ${ }^{11}$ In a lengthy response to the sermon, Madipoane Masenya and Lehlohonolo Bookholane argued that, although Skosana's efforts to speak out on HIV/AIDS should be welcomed, a number of significant criticisms can be made of his approach. They pointed out that the identification of Jesus with HIV should not be necessary for the church to break its silence on HIV/AIDS. ${ }^{12}$ Furthermore, the claim Jesus was HIV-positive may serve to individualise the pandemic:

What concerns us more, is the impact of such claims on the gains made through the public campaigns to highlight the systemic and structural nature of HIV and AIDS and the impact such sermons will have in order to personalise, individualise and internalise what is essentially and naturally a public matter. ${ }^{13}$

They also argued that it might distract attention from the role of those who "are responsible for the structural designs that create and perpetuate such miserable conditions". ${ }^{14}$ Above all, Masenya and Bookholane argued that it would be counterproductive to Skosana's intentions:

Our main concern with a sermon that seeks to encourage activism around the pandemic of HIV and AIDS by claiming that Jesus was HIV-positive is that it can only defeat the mission to which it seeks to be committed. In our view, such a claim can only do harm to the campaign for abstinence, faithfulness and the use of condoms; because if Jesus himself could be positive, who am I not to be, a believer on the ground may ask. ${ }^{15}$

A fuller discussion of the range of responses to Skosana from different critical perspectives is beyond the scope of this chapter. Instead, what follows will focus primarily on the reactions which saw the sermon as offensive or insulting. Some of these were highlighted in the international media coverage. For example, the Daily Mail in London reported on the controversy under the title "Jesus was HIV-positive: South African pastor sparks outrage with bizarre claim". ${ }^{16}$

These responses typically ignore Skosana's intention and wider discussions around HIV/AIDS prevention, and focus instead on the offensiveness of the sermon. For example, the BBC reported the reaction of Pastor Mike Bele, who officiates at the Nomzamo Baptist Church in nearby Gugulethu. Bele said most clergy in Khayelitsha and other Cape Town townships are strongly opposed to associating Jesus with HIV: "The subject of my Jesus being HIV-positive is a scathing matter," he says. "I believe no anointed leader with a sound mind about the scriptures and the role of Christ in our lives would deliberately drag the name of Christ to the ground". For Pastor Bele, portraying Jesus as HIV-positive means he becomes part of the problem,

Phumzile Zondi-Mabizela, cited Gerald West with Bongi Zenge, "Reading Job 'Positively' in the Context of HIV/AIDS in South Africa", Concilium, 4, (2004):112-113.

12 Madipoane Masenya \& Lehlohonolo Bookholane, "Towards an Ethical Reading of the Hebrew Bible in the Fight against HIV and AIDS", Old Testament Essay, 24:1, (2011):99.

Ibid., 97.

lbid.

Ibid., 99.

The Daily Mail (2 November, 2010), online at: https://dailym.ai/35m9WKW [Accessed 5 June 2016]. 
not the solution: "The pastor [Skosana] needs to explain how it came about for him to bring Christ to our level, when Christ is supreme and is God". ${ }^{17}$

Pastor Bele's outrage is focused on what he sees as the demeaning implication of Jesus as HIV-positive. The emotional force behind his complaint reveals what he felt was really at stake. He is not concerned with the history or science of the sermon, or the sermon's potential impact on people with HIV/AIDS, or the potential consequences for HIV-prevention work. Instead Bele's criticism (at least in the version reported here) focuses primarily on the perceived offence and the supposed insult.

As Skosana shows in his response to such criticism, his sermon is all the more important precisely because of this perception of insult. One of the consequences of the sermon was that it unveiled the victim-blaming and stigmatising which operates within society, and within the church, but which many in the church would usually deny.

The scathing attacks I've received from Christians are unbelievable ... They're saying you can't reconcile Jesus and Aids. They assume it means Jesus was promiscuous and had a louche lifestyle with many sexual partners. ${ }^{18}$

The HIV/AIDS stigma is a major obstacle to effective responses to HIV/AIDS. ${ }^{19}$ As Skosana points out, there seems to be an association of HIV/AIDS with the stigma linked to immoral behaviour in the minds of critics, like Bele, which makes it impossible for Bele to imagine Jesus as HIV-positive, and prompts him to see this connection as highly offensive. The reaction is not about history or science, but about perceived insult and offence.

In this context Bele's comments show that Skosana's sermon was in fact a highly effective way to draw out this perception and start a deeper discussion. The sermon exposed and excavated the HIV/AIDS stigma that church members typically seek to keep hidden. The HIV/AIDS stigma is all the more harmful because it is often hidden so well that church members may not themselves be aware of how strongly it influences them. These dynamics are further complicated because they are often disguised or hidden. Church members whose attitudes are influenced by the stigma are more likely to see themselves as acting in a correct and respectable way rather, than doing something wrong or uncompassionate. ${ }^{20}$ Thus the HIV/AIDS stigma is often both hidden from view and disguised as something more respectable.

The harm done by the HIV/AIDS stigma can therefore only be addressed if creative ways are found to confront the denial and bring the stigma out into the open.

17 Allie, "'Jesus had HIV' Sermon"; Samaraseker, "Jesus had HIV"; Smith, "Pastor's 'Jesus had HIV' Sermon".

18 Smith, "Pastor's 'Jesus had HIV' Sermon".

19 Donald Skinner \& Mfecane Sakhumzi, "Stigma, Discrimination and the Implications for People Living with HIVIAIDS in South Africa", SAHARA-J: Journal of Social Aspects of HIV/AIDS, 1:3:157-164 [https://doi.org/10.1080/17290376.2004.9724838]. Haddad, Religion and HIV; Byamugisha et al., Is the Body of Christ HIV Positive?

20 Rachel Vernon, "The Body of Christ is HIV Positive". In: Byamugisha et al. Is the Body of Christ HIV Positive? 
Skosana said: "It baffles me why in the church this [HIV/AIDS] is the most untalkedabout subject" ${ }^{21}$ The silence around HIV/AIDS is not a neutral and non-committal silence, but an oppressive and damaging silence that hides and sustains a destructive stigma. Furthermore, the judgemental silence encourages people with HIV/AIDS to self-stigmatise. Skosana explained further in an interview:

If I went to church and never heard the pastor talk about this, I would assume I must go home and die in silence. The message is that it's an unpardonable sin and we must just forget about HIV/Aids ... My responsibility as a pastor is to open a Bible and paint a picture of a God who cares for people and wants the best for them, not who judges them and is ashamed of them. ${ }^{22}$

To sum up, Skosana's sermon was never intended to be history or science, but rather a metaphorical connection of Jesus to HIV as a creative confession of Christ's suffering. It was bold and provocative, but in no way bizarre. The reservations offered by Masenya and Bookholane and other critics on the potential unintended negative consequences of the sermon are important, but more positive responses should also be noted. Of particular relevance to the argument here is that the sermon provoked particularly strong reactions from some who saw it as insulting and offensive. This reaction served to expose the stigmatising attitudes and values underlying these responses.

Insights from the sermon's capacity to reveal what might otherwise remain hidden and disguised are relevant to other issues where stigma is a major barrier to prevention initiatives. The rest of this chapter will suggest how this might also be significant for church responses to sexual violence and its stigma.

\section{Tearfund's Breaking the Silence (2013)}

The HIV/AIDS crisis opened up new ways within the churches to address sex and sexual ethics. Over time this disclosure prompted the church to give more attention to sexual violence. As an international Christian relief and development agency, Tearfund's work on HIV/AIDS helped prepare the way for its new programme addressing sexual violence. On 21 March 2011 the Tearfund report Silent No More (2011) was launched at an event at Lambeth Palace. ${ }^{23}$ Tearfund, the Anglican Communion, Restored, and Christian Aid, also used this event to launch a "We Will Speak Out" (WWSO) coalition of Christian-based NGOs, churches and organisations, and partners committed to ending sexual violence. ${ }^{24}$ Silent No More focused on conflict-related sexual violence in Liberia, the Democratic Republic of Congo and Rwanda. Breaking the Silence (2013) took the work on sexual violence further with South African case studies. ${ }^{25}$

Smith, "Pastor's 'Jesus had HIV' Sermon".

Ibid.

Tearfund, Silent No More: The Untapped Potential of the Worldwide Church in Addressing Sexual

Violence (Teddington, Middlesex: Tearfund, 2011).

"We Will Speak Out", online at: www.wewillspeakout.org [Accessed 18 August 2016].

Since then Tearfund has published further reports on sexual violence in other African countries and other conflicts. 
Tearfund's report Breaking the Silence draws on interviews conducted in townships and poor rural communities in South Africa. ${ }^{26}$ These were conducted in two locations in the Western Cape (Bredasdorp and Du Noon), and two locations in KwaZulu-Natal (around Pietermaritzburg and Durban). ${ }^{27}$ The whole report, as well as the data on which it is based, deserves careful attention. In what follows three aspects of the report which are especially relevant to Skosana's sermon will be discussed: the silence of survivors, the silence of the churches and the potential of the churches. ${ }^{28}$

\section{The Silence of Survivors and the Fear of Blame, Shame and Stigma}

Sexual violence is widespread in South Africa. Conservative estimates suggest that more than 580,000 rapes could have been committed in 2012, which would amount to one in every 86 people in South Africa. ${ }^{29}$ Yet the prevalence of sexual violence is consistently under-reported. During 2011 to 2012 more than 64,000 rapes were reported to the police, but "it is estimated that between 80 and $95 \%$ of rapes are not reported due to fear and stigma". ${ }^{30}$

This fear of stigma is often well justified. There is an extensive feminist literature on ways that survivors are frequently blamed or shamed for sexual violence. These 'victim-blaming' attitudes often imply that victims encouraged, or are in some way responsible, for what happened to them. The actions of perpetrators escape scrutiny and censure because they are seen as normal and to be expected, especially when it is sexual violence by men against women. By contrast, women's actions are viewed with a presumption of responsibility and a readiness to blame.

Breaking the Silence describes a readiness to 'judge and gossip'. ${ }^{31}$ Even if the survivor is not directly blamed for contributing to sexual violence in some way, she can

Tearfund, Breaking the Silence: The Role of the Church in Addressing Sexual Violence in South Africa, (Tearfund South Africa, 2013). Tearfund, Silent No More and Breaking the Silence both draw on fieldwork and analysis conducted by Elisabet le Roux at the Unit for Religion and Development Research, University of Stellenbosch.

27 On 2 February 2013 Bredasdorp was the location of a particularly brutal rape and mutilation of a seventeen-year-old woman, Anene Booysen, who died of her injuries shortly afterwards. The case sparked a national outcry and highlighted the extreme forms which sexual and genderbased violence can take. See Chanel September, "The Anene Booysen Story", Eyewitness News (1 November 2013), online at: http://bit.ly/2p3flpS

28 The three points discussed in this section in the light of Skosana's sermon are closely related - but not a direct match - to the three key points which the report itself highlights as a summary of its contents: "First, sexual violence is widespread across South Africa and has a deeply traumatising and damaging effect on survivors. Second, the church has often failed survivors of sexual violence. Many churches deepen the impact of sexual violence through their silence, stigma and discrimination. Some churches have not done enough to care for the marginalised or to speak out on their behalf. Third, the church is central to community life and has untapped potential to prevent and respond to sexual violence. It can provide care and support, stand alongside survivors seeking justice, and identify and challenge harmful attitudes and beliefs within society that perpetuate sexual violence"; Tearfund, Breaking the Silence, 3.

29 Tearfund, Breaking the Silence, 5.

$30 \quad$ Ibid.

$31 \quad$ Ibid., 6. 
still be judged negatively because of what happened. Survivors of sexual violence are often viewed as having been diminished, damaged or despoiled in some way. They are seen as having less worth or less dignity because of what happened, and may even be described as defiled or ruined. This tendency fits closely with Erving Goffman's influential work on stigma and spoiled identity: it is his understanding that the stigmatised person is "reduced in our minds from a whole and usual person to a tainted, discounted one". ${ }^{32}$ Even church members who might otherwise be caring and compassionate towards survivors can reinforce this negative perception and stigma. Social perceptions of shame and gender, and the association between sex and shame for women, are critical elements in the stigma of sexual violence.

Some Tearfund interviewees who reported sexual violence described the additional distress and re-victimisation they suffered in the reporting system. The institutions and authorities which should help survivors often fail to do so, and can make them feel worse rather than better. In the words of one survivor

[t]hey make you feel like you are the criminal. They are not sympathetic. Survivors keep silent because of the way we are treated when we go and report it. ${ }^{33}$

These victim-blaming reactions and responses reinforce the sense of shame and stigma, and the inclination towards maintaining silence, which many victims have already internalised from wider social attitudes to sexual violence. The church also shares a special responsibility in this alienation. When survivors are already coping with hostility and neglect from authorities and other agencies, further poor treatment within the church can be especially upsetting. A survivor reports on how "I have rejected all churches. Church members were the ones who hurt me the most".$^{34}$ It is little surprise, then, that so many cases go unreported. In the words of a survivor interviewed in Silent No More, "I choose to die silently. You're too scared to talk about it and you don't know who to tell" ${ }^{35}$ This non-reporting reinforces the silence and contributes to further offending and repeated victimisation in a destructive cycle. Another survivor reports that "I've been raped more than 20 times. It has numbed me. I don't have feelings. I can't trust anyone. It has broken me inside" ${ }^{36}$

\section{The Silence of the Church and the Reinforcement of Blame, Shame, and Stigma}

The self-imposed silence of survivors is often further reinforced by the silence of the churches. A survivor is cited as saying

[p]astors cry out from the pulpit: "We love people", "We want to help people". But as soon as you go with a real situation like someone being sexually violated, they will run. They sweep it under the rug. ${ }^{37}$

Some churches deepen the pain and grief associated with sexual violence through victim-blaming or a judgemental silence. Negative responses within the churches

32 Erving Goffman, Stigma: Notes on the Management of Spoiled Identity (New York and London:

Simon \& Schuster, 1963), 2.

Tearfund, Breaking the Silence, 7.

Ibid., 6.

Ibid., 4.

lbid., 5.

lbid., 6. 
are not necessarily explicit or direct, but can be expressed in a range of indirect and subtle ways, and especially through an unsympathetic silence. These church responses are often shaped by similar tendencies towards blaming and/or shaming the victim as in wider society, even if these are not directly spoken. It is precisely because these attitudes are not articulated explicitly that they persist under the surface and are left unexamined. When they are hidden from view in this way, they can undermine a compassionate response to sexual violence and shield harmful attitudes and behaviour from the ethical scrutiny they deserve.

The report refers to a disturbing normalisation of sexual violence. It cites a 2008 survey which found that " $28 \%$ of men in the Eastern Cape and KwaZulu-Natal provinces had raped a woman or girl. One third of these men said they did not feel guilty". ${ }^{38}$ The statistic that one third of men did not feel guilty for rape raises serious questions about social attitudes amongst men and how such attitudes can excuse and support sexual violence. Since the figure is so high, there can be little doubt that such attitudes are also shared by some within the churches. Even so, it seems likely that if asked directly, most church members would agree that sexual violence is wrong, and that the shame attached to sexual violence should be carried by the perpetrator not the victim-survivor. However, in practice this question is rarely asked. In the absence of an explicit question, the gendered nature of shame makes it much more likely that even those who see sexual violence as wrong will still associate shame with a female victim-survivor rather than a male perpetrator. The silence of the churches means that despite the obvious ethical self-contradictions in this victim-blaming and stigmatising, little is done to challenge these views or to critically examine the assumptions which support them.

\section{The Untapped Potential within the Churches to Address Sexual Violence}

A third key message from the report is much more positive. If the churches in South Africa can overcome their silences and reflect on their teaching and actions, they have an untapped potential to address sexual violence in their communities.

One aspect of this potential is the institutional presence of churches throughout South Africa. Churches are physically present in communities as pastoral institutions. No other social institution has the same geographical reach or physical presence as the churches. They can offer services for both rural and urban communities. Reaching out for other support services might require a trip to an unfamiliar organisation in the nearest town, or even a distant city, whereas the churches are well known and more readily accessible:

The church's reach goes beyond that of any other institution in South Africa. It is not only stable: it is also trusted. This is crucial when responding to the sensitive issue of sexual violence. ${ }^{39}$

A second aspect of the potential of the churches is that very few other institutions have the same moral authority or social influence as the churches. The churches have a social acceptance and social respect that exceeds many other social agencies

\footnotetext{
$38 \quad$ Ibid., 5.

39 Ibid., 10.
} 
and crosses many social divides. The churches are thus uniquely well placed to provide care and support for survivors, stand alongside those seeking justice, and identify and challenge harmful attitudes and beliefs within society that perpetuate sexual violence.

Despite this exceptional potential, Breaking the Silence indicates that the churches have not done enough to embrace the opportunities which are before them. It notes that " $[t]$ he current challenge to church leaders at both national and local levels is that the church should have a more profound impact on sexual violence".$^{40}$ Breaking the Silence calls for urgent action by the churches in South Africa to do more to end sexual violence and show care for its victims. It was used to launch the We Will Speak Out Campaign in South Africa on 25 November 2013, with support from Thabo Makgoba, the Anglican Archbishop of Cape Town.

In Tearfund's report Silent No More (2011), survivors of sexual violence in other African countries identified the church as the institution with the most potential to help them. ${ }^{41}$ Yet at the same time it also confirmed that in practice the churches generally remain silent on sexual violence and ignore the needs of victims. As noted above, the same silence on the part of churches is reported in Breaking the Silence as a key issue for the churches to address. Both reports suggest that the churches' silence is at least partly because many churches do not see tackling sexual violence as part of their biblical mandate, or central to their theological identity or missional purpose.

There have been some exceptional individuals, congregations and local organisations that are exceptions to this overall picture. Imaginative local initiatives demonstrate the church's capacity for powerful impact. Yet, on the whole, the churches have been slow to make sexual violence a priority and have failed to make their voices heard (Le Roux 2012, 2014). Whilst no church would actively endorse sexual violence, many churches are likely to say nothing and are thereby complicit with the status quo through silence. They have done little to critically interrogate their own teachings on gender relations and power, or to examine how these might contribute towards sexual violence.

To help the churches in these important initiatives, a more theologically grounded motivation for addressing sexual violence could make a powerful contribution. If church responses to sexual violence are seen as merely one strand of good works or pastoral action amongst many others, addressing sexual violence will inevitably struggle to claim church time and attention. Without a clearer theological mandate, many within the churches will find it hard to make sexual violence a priority. In view of the silence and stigma associated with sexual violence, it is more likely that it will be paid no more than lip-service and be largely marginalised and forgotten.

This risk of being sidelined raises a key question for Christian theologians, biblical scholars and church leaders: what theological and biblical resources are available

\section{$40 \quad$ Ibid.}

$41 \quad$ For a response to Silent No More that offers further background on the report itself and its potential theological significance, see David Tombs, "Silent No More: Sexual Violence in Conflict as a Challenge to the Worldwide Church", Acta Theologica, 34:2, (December, 2014), 142-60. Online at:

http://bit.ly/35e1y0h 
to ensure that churches are more actively engaged, and their responses to sexual violence are firmly part of a solution rather than part of the problem? In particular, what biblical and theological resources are available to address the silence and stigma associated with sexual violence, and the mistaken and harmful assumptions connected to this within churches?

A sustained investigation of attitudes towards blame and shame could help transform church responses to survivors. This would support a more informed and more caring attitude to survivors. A deeper awareness of blame and shame connected to sexual violence could shape a pastoral response which affirms the human dignity of all, regardless of what they might have been subjected to. Rather than deepening the damage and despair of sexual violence, the church can help lift up survivors. It can seek to restore their sense of self-worth and value when these qualities have been damaged or lost.

Much of the biblical and theological work that has been done on sexual violence has focused on critiquing how Christian teaching can often be part of the problem. Although this is essential work, it needs to be supported by works which address how the Bible and theology can also be part of the solution. The reactions to Skosana's sermon offer insights that theological work on sexual violence might draw upon. The sections below will suggest that in terms of historical evidence there is an even stronger reason for making the connection between Jesus and sexual violence. Making this acknowledgment more public will almost certainly prompt hostile reactions, but will serve a positive purpose in the long term.

\section{Jesus as Victim of Sexual Violence}

One of the greatest silences in Christianity is silence on the sexual violence that typically accompanied Roman crucifixions. There has been extensive work on Roman sexual politics, gender identity, notions of masculinity and femininity, and the symbolism of sexual penetration. ${ }^{42}$ Yet this has rarely been recalled as a significant context for reading New Testament passages on crucifixion. Academic literature which views and names the experience of Jesus in terms of such violence has only recently started to emerge. My own article "Crucifixion, State Terror, and Sexual Abuse" (1999) appears to be the first to do so. ${ }^{43}$ The Australian Catholic priest Michael Trainor has also written independently along similar lines. ${ }^{44}$ In both cases, a concern with current context has shaped the biblical reading. My article draws on accounts of torture and prisoner abuse in Latin America. Trainor links his reading to the sexual abuse scandal in Australia. It is not that these contemporary contexts determine the meaning of the biblical context, or project something into

42 Judith P. Hallett \& Marilyn Skinner (eds.), Roman Sexualities (Princeton, NJ: Princeton University Press, 1997). Craig A. Williams, Roman Homosexuality: Ideologies of Masculinity in Classical Antiquity (Oxford: Oxford University Press, 1999).

43 David Tombs, "Crucifixion, State Terror, and Sexual Abuse", Union Seminary Quarterly Review 53,(Autumn 1999):104. Online at: http://bit.ly/2VpE97m

44 Michael Trainor, "Sexual Abuse and Luke's Story of Jesus". In: H.D. Regan (ed.), Child Sexual Abuse, Society, and the Future of the Church (Adelaide: ATF Australia, 2013) [https://doi.org/10.2307/j. ctt163t9qr.6]. Michael Trainor, Body of Jesus and Sexual Abuse: How the Gospel Passion Narrative Informs a Pastoral Approach (Eugene, OR: Wipf \& Stock Publishers, 2014). 
them which is not already there. Rather the contemporary contexts open up the texts from different perspectives to show how the texts might be read in new ways. The contexts encourage attention to features which might be missed or neglected. They give voice to what is otherwise so often left silent.

My own initial works suggest at least three areas of Jesus' mistreatment which invite further research in terms of sexual violence: the stripping and exposure; possible other sexualised abuses in the Praetorium; the unspeakable violence of the cross.

The stripping and public exposure are particularly important because they are explicitly attested. As I have argued before:

[b]ased on what the gospel texts themselves indicate, the sexual element in the abuse is unavoidable. An adult man was stripped naked for flogging, then dressed in an insulting way to be mocked, struck and spat at by a multitude of soldiers before being stripped again (at least in Mark 15.19 and Matthew 27.30) and re-clothed for his journey through the city - already too weak to carry his own cross - only to be stripped again (a third time) and displayed to die whilst naked to a mocking crowd..$^{45}$

Social awareness and social attitudes to sexual violence have changed so dramatically since this passage was written that the stripping of Jesus is now much less likely to be dismissed as insignificant. The \#MeToo movement has created a new context in which stripping and enforced exposure are less likely to be dismissed as incidental or unimportant. Yet, it is still easy to pass over these passages without pausing to reflect on their disturbing elements. Part of the reason for this omission is that the understanding of the passage is often shaped by a prior understanding influenced by Christian art. Depictions of the stripping in Christian art, including portrayals in the tenth station of the cross, typically show Jesus as surrounded by just a handful of others, and often no more than two, who are not necessarily in military uniforms. In some pictures his assailants seem to be assisting him to undress rather than forcibly stripping him of his clothing. The indication in Mark 15:16b that "they called together the whole cohort" of soldiers sounds a very different note. The assembly of more than five hundred soldiers to view the forced stripping of a prisoner would have heightened the sense of vulnerability, humiliation and threat involved with the stripping. ${ }^{46}$

Skosana has also apparently referenced the emotionally charged significance of the naked body in some of his writing. According to Zvomuya, in explaining the connection between black South Africans and Easter in Interpreting Easter, Skosana writes that:

[t]hey have an immediate identification with a bruised and naked body of a stranger hanging on the cross. That stranger has become their symbol of suffering and hope, a depiction of their daily struggle. When they look up at the cross, they look at themselves. ${ }^{47}$

45 Tombs, "Crucifixion, State Terror, and Sexual Abuse", 104.

46 Katie Edwards \& David Tombs. 2018. "\#HimToo - Why Jesus Should be Recognised as a Victim of Sexual Violence", The Conversation, 23 March 2018; online at: http://bit.ly/33kYca1

47 Percy Zvomuya, "Jesus Christ Lived in the Townships", Mail and Guardian, 21 Apr 2011. Online at: http://bit.ly/326prFa [Accessed 10 July 2016]. 
This identification, along with the use of stripping and exposure of prisoners in apartheid detention, deserves more attention for a deeper understanding of the deliberate humiliation of Jesus.

The second area where questions might be asked relates to further mockery and humiliation that may have taken place in the Praetorium, but which has not been recorded in the text. Stripping and naked exposure are often a precursor to other forms of sexual violence. It is impossible to know with certainty what else may have taken place. However, a careful reading of the texts in the light of accounts of prisoner abuses in recent times such as at Abu Ghraib suggests that the possibility of further abuses cannot be dismissed. Likewise, careful reading of Roman practices and Roman attitudes to sexual violence make this a very real possibility. The Romans were known to use a wide range of kinds of sexual violence and violations against those whom they wished to humiliate. Executions were often the culmination of a sequence of abuses, and earlier steps in the punishment could include rape, burning of body parts, castration and mutilation.

A third area for investigation, alongside the stripping and the possibility of other humiliation in the Praetorium relates to the cross itself. The cross can and should be viewed as an instrument of torture as well as execution. Viewing the cross in terms of torture helps to ask a question about crucifixion and sexual violence. It is very unusual to ask this question and there is very is little in Christian art which encourages it. Even so, there is significant historical evidence which points in this direction. The Roman historian Seneca records what he saw in the campaign in Bithynia, in his Letter to Marcia on Consolation (dated about $40 \mathrm{CE}$ ):

I see crosses there, not just of one kind but made in many different ways: some have their victims with head down to the ground; some impale their private parts; others stretch out their arms on the gibbet. ${ }^{48}$

It is not completely clear what the genital impalement witnessed by Seneca involved, but it suggests that Roman crucifixion could be much closer to earlier impalement practices than has usually been appreciated. When this is placed alongside other evidence pointing to the sexualised nature of Roman crucifixions, it challenges the common account that crucifixion was a development away from ancient impalement practices. Most discussions of crucifixion follow Martin Hengel's classic work. ${ }^{49}$ They recognise the link between crucifixion and impalement, but put the emphasis on the discontinuity between the two. This implies that Roman crucifixion shared little with earlier impalements. Seneca provides clear evidence that, in fact, Roman crucifixions could involve sexual impalement. This would presumably have been done to signify humiliation and to announce Roman power. Since there is a scholarly consensus that the contrast between the humiliation of the victim and the power of Rome was precisely what crucifixion was meant to convey, it is startling how little consideration has been given to how this might be done

49 Martin Hengel, Crucifixion: In the Ancient World and the Folly of the Message of the Cross (London: SCM Press, 1977), 25). 
through sexual violence. The otherwise excellent and comprehensive recent survey by John Cook ${ }^{50}$ does not address this question. ${ }^{51}$

References to crucifixion are relatively plentiful in Roman literature, but also relatively scant on detail. Frequently references to crucifixion are no more than a passing mention of the punishment. In many cases a euphemism such as 'slave's punishment' is used instead of explicitly naming crucifixion. It seems that crucifixions were considered unspeakable in Roman society, and there is good reason to suspect that it was the shame and stigma associated with sexual violence that was the reason for this. It is possible that the euphemism 'slave's punishment' is a tacit reference to sexual violation. There is no question that crucifixion was a punishment particularly associated with slaves, along with bandits and rebels, and hence 'slave's punishment' would have been readily understood as crucifixion. However, what might give the term a less obvious further meaning is that since slaves were the property of their masters, a slave was vulnerable to sexual violation at any time. To be a slave was to be without control over one's body. Both male and female slaves were subject to their master's orders and expected to serve their master's sexual wishes. The term 'slave's punishment' could therefore have had a more direct suggestion of sexual violation than is normally assumed.

\section{Confronting the Stigma Around Sexual Violence}

In my experience sharing this research, when people first hear the idea that Jesus was a victim of sexual violence, they usually assume they have misheard, or that the suggestion is only metaphorical, or that it self-evidently mistaken. Yet when the biblical passages are read and the historical evidence is discussed, people are often amazed that they have never heard this before or seen it for themselves. Moreover, the fact that something they now see as so obvious has been hidden in plain sight for so long prompts new questions. What influences what is seen and what not seen, what determines what is said and what is not said?

As has already been mentioned, Christian art is an important factor in how crucifixion is seen. The dominant representation of crucifixion in Christian art adds to the difficulty in imagining the strong connection between crucifixion and sexual violence. Christian art typically offers a highly sanitised version of crucifixion which has been so entrenched in Christian tradition that to question it can initially seem bizarre. Thus, although many ordinary church members today are aware of the scholarly consensus that Christ was crucified naked, this form of sexual humiliation is rarely represented in ways that acknowledge its disturbing nature or encourage recognition of it as a form of sexual violence.

The sensitivity of the subject and wider silences around sexual violence and male victims are also important factors. A primary reason that the sexual violence against Jesus has not been given the attention it deserves is that at first glance the mere idea 
appears not just mistaken but offensive and insulting. For those who take the Bible seriously, it is assumed that little of value is to be gained by even considering the possibility. This sceptical reaction is understandable but misguided. Skosana shows this blindness in response to the reactions of those offended at his metaphorical identification of Jesus as HIV-positive. The reactions which claim it is offensive to say Jesus was a victim of sexual violence need to be challenged and addressed.

Discussion of the sexualised elements in the humiliation and abuse of Jesus clearly raises sensitive and disturbing questions that the Christian tradition has usually avoided. It will take time and care for this conversation to develop in a way that is serious rather than sensationalist. However, Skosana's sermon offers encouragement that, if the churches are willing to face up to these questions, this difficult process will eventually prove worthwhile and may have extraordinary potential to make a positive difference. Recognition that Jesus was a victim of sexual violence could help the churches in South Africa, and in other contexts, to break their silence on sexual violence. It can provide a biblical and theological basis to develop a more honest and more constructive approach to sexual violence in dialogue with survivors of sexual violence.

The conventional reactions of blaming or stigmatising a victim of sexual violence are disrupted when the victim is Jesus. Powerful dynamics in the theological tradition prevent this default response. Jesus is typically recognised within the churches as being 'without sin'. This chapter is not the place to ask what 'without $\sin ^{\prime}$ really means in this context, or to discuss its merits and limitations. The convention is more to highlight the self-evident failure of the victim-blaming response when Jesus is recognised as the victim. It is clear that Jesus is not to be blamed. This convention can then lead onto questioning why victim-blaming is so readily assumed for other victims. It may be precisely because acknowledgement of the evidence that Jesus was a victim of sexual abuse is so disruptive of these stigmatising assumptions that some people react so fiercely to the suggestion Jesus was abused and dismiss it as insulting and offensive. There is a lot more at stake Christologically than first appears.

The claims that Skosana's sermon was insulting and offensive show why attention to Jesus' experience of sexual violence matters in the present. It can help expose and address the stigmatising and blame that prevent the churches from responding more appropriately to sexual violence. Recognising these dynamics can contribute to a transformative change within the churches that makes a practical difference to the way that churches relate to survivors.

This act of discerning is not to suggest that the churches should take sexual violence seriously only because of the experience of Jesus. Nor do the churches 'need' Jesus to have been abused for sexual abuse to be important, because only his experience is regarded as important. It is, however, appropriate to acknowledge that Jesus of Nazareth has a particular significance and status within the churches, and his experience of crucifixion and resurrection are central to the way the churches understand themselves and their work.

Likewise, it is not to suggest that Jesus should be acknowledged as a victim of sexual abuse regardless of the historical and textual evidence which supports or 
contradicts this. Whilst there might be some value in a metaphorical identification irrespective of the historical and textual evidence, that would clearly be a very different matter from the historical identification of sexual violence suggested here. The historical identification must be based on the evidence quite separate from the positive consequence or purpose that this identification may serve, but this does not preclude clearer recognition of this historical evidence from also having positive consequences in the present.

The argument of this chapter is that naming Jesus as a victim of sexual violence would be a justified and revolutionary step within the churches. This suggestion will need to be reflected upon further with attention to whether or not survivors of sexual violence see it as helpful or not. Understanding more of survivor responses is a crucial next step for this work and research along these lines has barely begun. However, whilst the views of survivors on the difference that acknowledging Jesus as a victim of sexual violence might make is critically important, it would be wrong to see this discussion as a concern only for survivors. It is also relevant to the whole church. Just as HIV/AIDS prompted new theological reflection on the whole church as body of Christ (1 Corinthians 12:27) in terms of HIV, so sexual violence provides a new context for new Christological insights and ecclesiological awareness of the church as the abused body of Christ. What does it mean for the whole church if it is the current body of the sexually abused Christ? If the Christological and ecclesiological implications of the sexual violence of crucifixion are taken seriously, they offer a strong counter-message to the mistaken attitudes of victim-blaming and stigmatising which still prevail within churches.

\section{Conclusion}

The churches have extraordinary potential to show transformative leadership on issues of sexual violence in South Africa and in other countries. Recent biblical and historical research which suggests that Jesus himself should be recognised as a victim of sexual violence could offer a powerful resource for this work. Facing up to the reality of crucifixion and what it meant in terms of sexual violence will not be an easy or straightforward process. There will be a lot of work involved in talking through the ideas in a way that is historically, biblically, theologically and pastorally responsible. This task will need to be essentially attentive to the responses of survivors, but it is a conversation for the whole body of the church. The churches should embrace opportunities to face up to these issues and become better at these conversations. As shown in Tearfund's Silent No More and Breaking the Silence, this need presents an important opportunity to be embraced. As Skosana's sermon suggests, the initial reaction to this acknowledgement will often be to dismiss it as offensive or blasphemous. It is precisely this reaction, however, which creates the opportunity for a fuller transformation to occur. It is not just a matter of correcting the historical record, it also reveals something deeper about hidden attitudes. It makes a real difference to the ministry of the church and the very being of the church as the body of Christ. A similarly bold approach to addressing hidden attitudes and stigma would serve the churches well in their response to sexual violence. 